\title{
A rotating piston engine with electric generator in serial hybrid propulsion system for use in light aircraft
}

ARTICLE INFO

Received: 15 July 2021

Revised: 27 July 2021

Accepted: 17 August 2021

Available online: 1 September 2021
Analysis of the possibility of using a rotary engine based electric generator to propell a powered sailplane. The paper presents analysis of utilising Wankel type enine as a power input for an electric generator in the motor glider propulsion system. This generator would be a part of the propulsion system of a hybrid motor glider using the AOS 71 motor glider airframe. In the research, the rotational characteristics of the LCR 407ti wankel engine were determined experimentally. Driving torque run, power and fuel consumption were determined as a function of engine speed. The obtained results are presented in diagrams. The conceptual diagram of the hybrid drive is presented. The electric generator was selected and its effectiveness, as well as the effectiveness of entire propulsion system was assessed from the motor glider's performance point of view. Basing on the research conducted, conclusions were drawn and there were indicated the objectives and directions of further research on hybrid propulsion with specific aerodynamic and mass limitations of the aircraft.

Key words: hybrid, combustion engines, motor glider, rotary engine, Wankel engine, hybrid propulsion

This is an open access article under the CC BY license (http://creativecommons.org/licenses/BY/4.0/)

\section{Introduction}

Aviation designs, especially in relation to light aircraft, are increasingly often equipped with electric propulsion [1, 2]. The electric motors drive the propellers to generate thrust. The use of electric motors brings a number of advantages such as [15]: a) low level of vibrations generated by the drive unit, b) high unit power (power to weight ratio of the electric motor), c) flat torque waveform available from low engine speed, thanks to which the propeller can cooperate with the engine at high efficiency. The energy needed to run these motors can be obtained from batteries. This is the easiest way to configure such a power unit. Unfortunately, the still large mass of batteries and their low energy density limit the payload carried on board the plane and the range of the aircraft [5-10]. To overcome these disadvantages a hybrid propulsion can be considered a propulsion in which an additional source of energy, especially an internal combustion engine, will be installed on board. The application where the electric motor driving the propeller draws energy from a set of batteries and a generator driven by an internal combustion engine is called a series hybrid [7]. The diagram of the series hybrid drive system is shown in Fig. 1 [8].

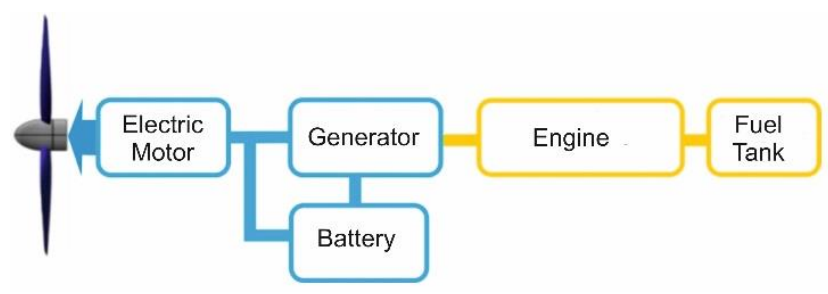

Fig. 1. Series hybrid system

In systems with a high degree of hybridization, the combustion unit and the electric generator are used to recharge the battery and maintain its capacity, thus increasing the range and duration of the flight. The system of an internal combustion engine and an electric engine cooperating as an electric energy generator is called a range extender in the English literature. The article will describe the method of selecting such a propulsion for a light aircraft.

\section{Description of the research object}

The research object used to carry out the research is the AOS H2 motor glider airframe. developed by the consortium of Rzeszów University of Technology, Warsaw University of Technology, AGH University of Science and Technology and Zakład Szybowcowy Jeżów Henryk Mynarski. It is in use at the Department of Aerospace Engineering of Rzeszów University of Technology as a research object. It is built in the arrangement of a cantilever high-wing with classic empennage. The materials used for its construction were mostly carbon fibre reinforced epoxy composites, with some parts made of glass and aramid fibers. The powered sailplane has a single-spar wing with an auxiliary rear spar. The fuselage with the tailplane is a single-piece semimonocoque structure. The aircraft has a hybrid propulsion, where the energy needed for take-off and flight comes from both the Li-Poly battery pack, located in the front part of the fuselage, and the hydrogen fuel cell, located behind the pilot's cabin in the fuselage. The power unit consists of the EMRAX 268 engine located on a fixed mast in the rear part of the fuselage and a two-bladed wooden propeller. The view of the powered sailplane is shown in Fig. 2.

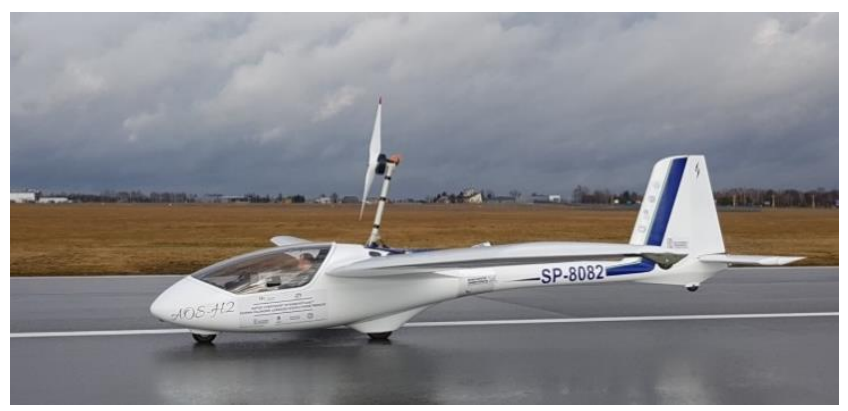

Fig. 2. The AOS H2 motor glider 
Table 1 shows the basic data of the airframe, while Fig. 3 present the values of power required for the flight for this airframe depending on the flight speed.

Table 1. Basic data of the AOS H2 motor glider $[13,14]$

\begin{tabular}{|l|c|c|}
\hline Wing area & $\mathrm{S}\left[\mathrm{m}^{2}\right]$ & 15.8 \\
\hline Wing span & $\mathrm{R}[\mathrm{m}]$ & 16.4 \\
\hline Aspect ratio & $\Lambda$ & 17 \\
\hline Maximum take-off mass & $\mathrm{M}_{\max }[\mathrm{kg}]$ & 660 \\
\hline Minimum motor glider mass & $\mathrm{M}_{\min }[\mathrm{kg}]$ & 500 \\
\hline
\end{tabular}

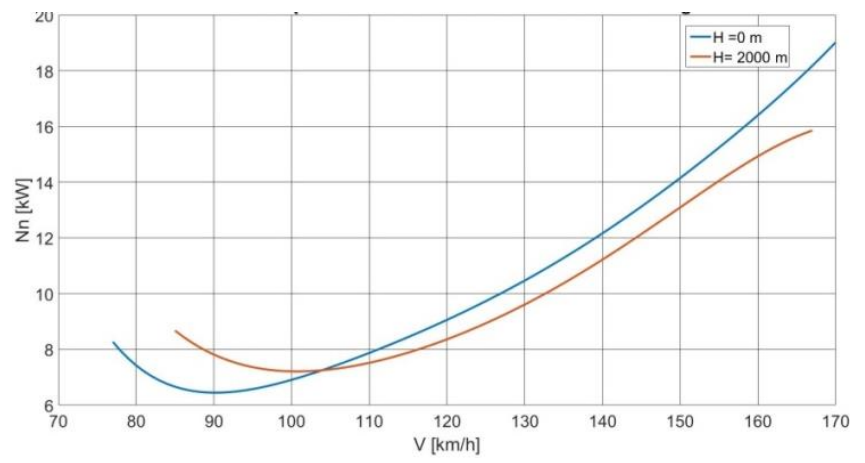

Fig. 3. Power required for flight in the function of flight speed - for the AOS H2 motor glider; $M_{\max }=660 \mathrm{~kg}[13,14]$

In the analyzed case, the hydrogen fuel cell was replaced with an internal combustion engine cooperating with an electric generator. The diagram of this drive is shown in Fig. 4.

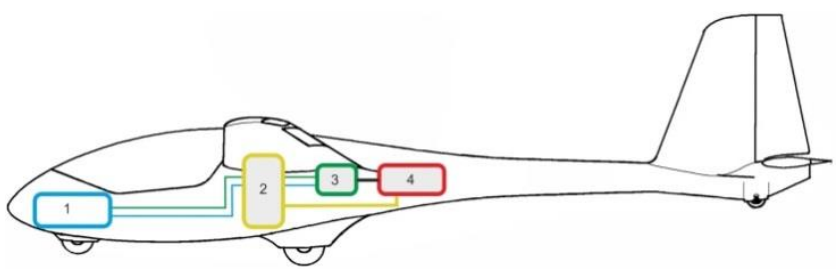

Fig. 4. Diagram of the hybrid propulsion system with an internal combustion engine for the AOS motor glider: 1 - battery, 2 - fuel tank, 3 - Emrax 188 engine working in generator mode, 4 - Wankel AG 407 TGi engine

\section{Cooperation of a rotary engine and an electric generator}

In the serial hybrid system adopted for analysis, the generator should meet the following assumptions:

- high unit power,

- low level of vibrations generated by the drive unit,

- easy-to-use,

- high level of reliability [15].

In the analysis, the Wankel AG 407TGi rotating piston engine was selected to drive the electric generator. This choice was dictated by the advantages of rotary piston engines, such as low engine weight, low vibration levels and high drive torque compared to reciprocating piston engines. The engine runs on a mixture of gas and two-stroke oil in the ratio of 100:1 - which significantly simplifies its design and weight (no lubricating oil system needed).

Table 2 presents a comparison of selected data of several internal combustion engines with a similar power range used in general aviation.
Table 2. Technical data of internal combustion engines[15, 16]

\begin{tabular}{|l|c|c|c|c|}
\hline Engine & & $407 \mathrm{TGi}$ & $\begin{array}{c}\text { Rotax } \\
125\end{array}$ & $\begin{array}{c}\text { Rotax } \\
28 \\
\text { Max }\end{array}$ \\
\hline $\begin{array}{l}\text { Maximum engine } \\
\text { power }\end{array}$ & $\mathrm{N}_{\max }[\mathrm{kW}]$ & 31.5 & 25 & 28 \\
\hline Maximum torque & $\mathrm{M}_{\max }[\mathrm{Nm}]$ & 51 & 22 & - \\
\hline Engine mass & $\mathrm{m}_{\mathrm{s}}[\mathrm{kg}]$ & 20 & 29 & 58 \\
\hline $\begin{array}{l}\text { Revolutions for } \\
\mathrm{M}_{\max }\end{array}$ & $\begin{array}{c}\mathrm{n}_{\mathrm{Mmax}} \\
{[\mathrm{rev} / \mathrm{min}]}\end{array}$ & 4000 & 10,500 & - \\
\hline
\end{tabular}

Table 2 shows that the Wankel engine has a relatively high unit power indicator (power related to the dry engine mass) among the remaining engines. In addition, it has a much higher torque than the 1-cylinder Rotax engine, which is available at low rotational speed. An additional advantage of using this type of engine will be less vibrations generated by a rotary engine than a traditional highspeed single-cylinder unit, which will favourably affect the fatigue strength of the engine and airframe structure.

In order to determine the scope of cooperation, it was necessary to determine the rotational characteristics of the combustion engine. Figure 5 shows the view of the test stand with an electro-swirl brake.

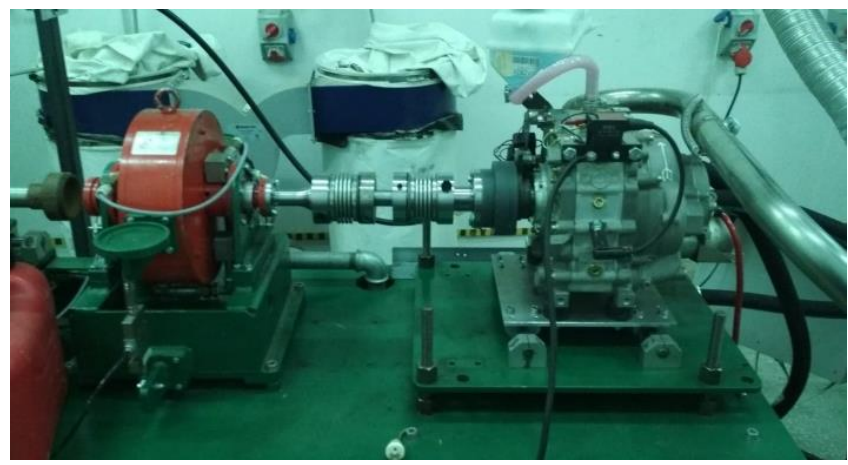

Fig. 5. Stand for testing engine characteristics

The determined rotational characteristic, presented in Fig. 6.

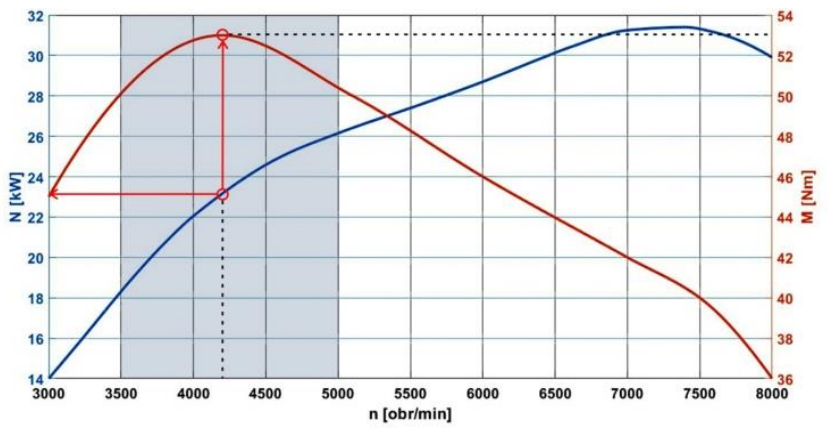

Fig. 6. Rotational characteristics of the 407 tgi

The characteristics presented in Fig. 6 show that the highest torque values of the Wankel engine (above $28 \mathrm{Nm}$ ) range between $3500 \mathrm{rpm}$ and $5000 \mathrm{rpm}$, while the maximum torque $(53 \mathrm{Nm})$ corresponds to the power of about 22.5-23 kW. In these ranges the engine achieves its best thermal efficiency, which means the ratio of the power delivered to power consumed is highest with the highest 
torque parameters that the engine can achieve. At the same time, the engine manual [17] provides the value of the minimum unit fuel consumption $(0.3 \mathrm{~kg} / \mathrm{kWh})$ for the rotational speed of $4000 \mathrm{rpm}$, which corresponds to the power developed by the engine at the level of $22 \mathrm{~kW}$. This range of combustion engine operation was adopted as the most favorable for regenerative operation.

For the cooperation of the internal combustion engine and the electric motor, the operating range of the electric motor should be selected so that - the characteristics of the electric motor (in particular, the ratio of power to the obtained revolutions) matched the characteristics of the internal combustion engine in the range close to the rotational speeds of the piston engine shaft corresponding to the ranges of maximum torque and the lowest specific fuel consumption - this is to ensure high efficiency of generating electricity - in the event of an emergency, when it is necessary to increase electricity production (beyond the range of steady operation), the electric motor should develop a maximum power greater than the maximum power of the internal combustion engine - this is to avoid damage to the electric motor [12]. Emrax 188 engine was chosen as the generatig unit with the following technical data (given in Table 4).

Table 4. Technical data of the Emrax 188 engine [16]

\begin{tabular}{|l|c|c|}
\hline Engine & Emrax 188 & - \\
\hline Continuous power & $\mathrm{N}_{\text {const }}[\mathrm{kW}]$ & 32 \\
\hline Peak power & $\mathrm{N}_{\max }[\mathrm{kW}]$ & 50 \\
\hline Continuous torque & $\mathrm{M}_{\text {const }}[\mathrm{Nm}]$ & 60 \\
\hline Engine mass & $\mathrm{m}_{\mathrm{s}}[\mathrm{kg}]$ & 6.8 \\
\hline
\end{tabular}

Together with the factory-dedicated control system [16], this engine is able to operate in generator mode with the efficiency of $98 \%$.

As can be seen from Table 4, the choice of this engine was dictated by similar values of the obtained maximum continuous power. Moreover, the Emrax 188 and Emrax 268 powering the propeller, belong to the same group of engines. Hence completing the entire propulsion and integration of the electrical system will be easier based on previous experience

Figure 7 presents the characteristics of the Emrax 188 and Wankel 407TGi engines. The characteristics of the Emrax engine were obtained from the manufacturer's manual [16].

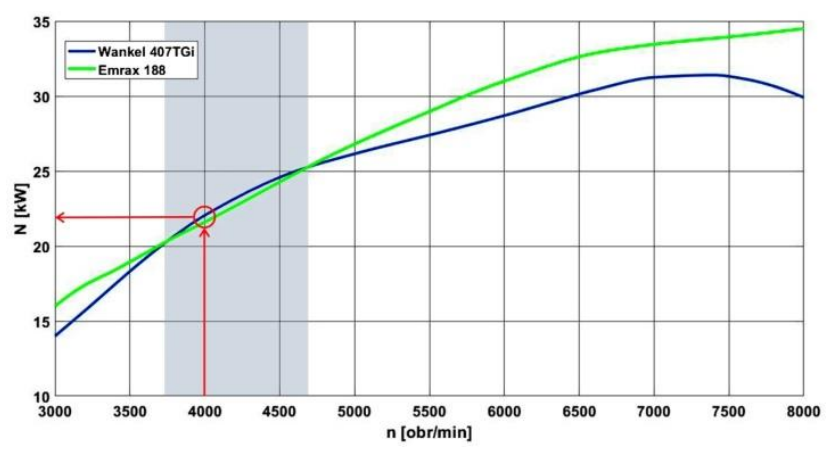

Fig. 7. Rotational characteristics of the $407 \mathrm{tgi}$
On the basis of the characteristics of the engines, it can be concluded that the most favorable operating range of the generator set will be the range from $3700 \mathrm{rpm}$ corresponding to $20 \mathrm{~kW}$ of power, to $4700 \mathrm{rpm}$ corresponding to $25 \mathrm{~kW}$ of power. At these points, the characteristics of the motors intersect, and between these points the characteristics nearly overlap, differing of up to about $0.5 \mathrm{~kW}$.

Due to the fact that the engine with a rotating piston achieves the lowest specific fuel consumption at $22 \mathrm{~kW}$ of developed power at $4000 \mathrm{rpm}$ of the engine rotational speed, this operating point was adopted for the generator operation. The fuel mass assumed to run the generator is $7 \mathrm{~kg}$. The total weight of the fuel, fuel system, internal combustion engine, electric engine and their accessories was approximately estimated on the basis of the technical parameters of the elements of the proposed modification. A mass balance of the energy source was made in order to relate it to the take-off mass of the aircraft. The analysis is summarized in Table 5.

Table 5. Specifications of the hybrid battery set

\begin{tabular}{|l|c|}
\hline System & Mass [kg] \\
\hline Fuel tank+fuel sstem & 15 \\
\hline Engine inverter & 7 \\
\hline High-current wiring & 7,3 \\
\hline Battery set & 60 \\
\hline Battery inverter & 8 \\
\hline Generator inwerter & 10 \\
\hline Wankel 407 tgi ice & 25 \\
\hline Fuel & 7 \\
\hline Generator (Emrax 188) & 7 \\
\hline Generator control unit & 30 \\
\hline Complete system & 176.3 \\
\hline
\end{tabular}

In relation to the take-off weight of $660 \mathrm{~kg}$, the weight of the drive unit is $26 \%$ of the take-off weight. The selected generator system works with a set of batteries of the parameters given in Table 6.

Table 6. Specifications of the hybrid battery set

\begin{tabular}{|l|c|c|}
\hline Battery type & Li-Poly & - \\
\hline Capacity & $\mathrm{C}[\mathrm{Ah}]$ & 16 \\
\hline Voltage & $\mathrm{U}_{\text {bat }}[\mathrm{V}]$ & 355 \\
\hline
\end{tabular}

After determining the appropriate range of cooperation between the internal combustion engine and the electric engine, it is possible to determine the energy stored on board the aircraft using the following formula [1]:

$$
\mathrm{E}=\mathrm{I} \cdot 3600[\mathrm{~s}] \cdot \mathrm{U}_{\text {bat }}+\eta_{\text {gen }} \cdot\left(\mathrm{N}_{\mathrm{s}} \cdot \mathrm{t}_{\mathrm{s}}\right)
$$

were $\mathrm{t}_{\mathrm{s}}$ - generator working time

$$
\mathrm{t}_{\mathrm{s}}=\frac{\mathrm{m}_{\mathrm{pal}}}{\mathrm{SFC} \cdot \mathrm{N}_{\mathrm{s}}}
$$

where: SFC - specific fuel consumption, Ns - engine power during generator operation mode.

The energy stored on board the powered sailplane is sufficient for 2 hours and 40 minutes of flight at a speed of $100 \mathrm{~km}$ per hour after take-off at an altitude of $500 \mathrm{~m}$.

The presented range value was calculated by dividing the energy stored on board by the power necessary to main- 
tain level flight under the selected flight conditions, related to the efficiency of the engine:

$$
\mathrm{t}=\frac{\mathrm{E}_{\mathrm{POZ}}}{\frac{\mathrm{N}_{\mathrm{N}}}{\eta_{\mathrm{S}}}}
$$

The methodology of determining energy parameters for the AOS $\mathrm{H} 2$ motor glider was presented in the doctoral dissertation [12].

For comparison, the AOS 71 powered sailplane with electric drive for the same flight conditions will be able to use the energy stored in the batteries only for about 40 minutes.

\section{Results of research conducted and conclusions}

Based on the presented research, it can be concluded that in the application of a series hybrid, the rotating piston engine provides sufficient performance. Compared to other piston engines of similar power, it has a lower weight, and due to its design, it generates a lower level of vibrations.
This is extremely important in relation to aircraft construction. In addition, a Wankel engine operating at a fixed rotational speed of the engine shaft should maintain high reliability and durability (which will be subject to further research by the authors of the article). With regard to purely electric propulsion, the use of serial hybrid propulsion, assuming unchanged take-off weight, allowed for a significant increase in the duration of the unit's operation, which will translate into an increase in the endurance and range of the flight.

The presented research shows the achievements of the authors to date in the use of a rotating piston engine as a drive for an electric generator. Currently, detailed studies of the performance characteristics of the internal combustion engine are being carried out (in cooperation with Bosmal). The next step will be the integration of the combustion and electric units.

\section{Bibliography}

[1] AYAR, M., GULEREN, K.M., KARAKOC, T. Motor selection process with AHP on mini electric UAV. International Symposium on Electric Aviation and Autonomous Systems ISEAS, Kiev 2018.

[2] BREJLE, B., MARTINS, J. Electric, hybrid, and turboelectric fixed-wing aircraft: a review of concepts, models, and design approaches. Progress in Aerospace Sciences. 2019, 104, 1-19. https://doi.org/10.1016/j.paerosci.2018.06.004

[3] DE VRIES, R. HOOGREEF, M., VOS R. Preliminary sizing of a hybrid-electric passenger aircraft featuring over-the-wing distributed-propulsion. American Institute of Aeronautics and Astronautics. 2019. https://doi.org/10.2514/6.2019-1811

[4] DONATEO, T., SPEDICANTO, L. Fuel economy of hybrid electric flight. Applied Energy. 2017, 206, 723-738. https://doi.org/10.1016/j.apenergy.2017.08.229

[5] FEFERMANN, Y., MAURY, C., CLELIA, C. et al. Hybridelectric motive power systems for commuter transport applications. $30^{\text {th }}$ Congress of the International Council of the Aeronautical Sciences. Daejeon 2016.

[6] FILLIPPONE, A. Flight performance of fixed and rotary wing aircraft. Butteeorth-Heinemann 2006, USA.

[7] FINGER, F.D., BRAUN, C., BIL, C. A review of configuration design for distributed propulsion transitioning VTOL aircraft. 2017 Asia-Pacific International Symposium on Aerospace Technology. Seoul 2017.

[8] FINGER, D.F., GÖTTEN, F., BRAUN, C. et al. On aircraft design under the consideration of hybrid-electric propulsion systems. ZHANG X. (ed.) The Proceedings of the 2018 AsiaPacific International Symposium on Aerospace Technology

Maciej Kalwara, MEng. - Faculty of Mechanical Engineering and Aeronautics, Rzeszow University of Technology.

e-mail:kalmac@prz.edu.pl
(APISAT 2018). Lecture Notes in Electrical Engineering. 2019, 459. Springer. Singapore.

https://doi.org/10.1007/978-981-13-3305-7_99

[9] FINGER, F.D., BRAUN, C., BIL, C. Case studies in initial sizing for hybrid-electric general aviation aircraft. 2018 AIAA/IEEE Electric Aircraft Technologies Symposium. 2018. https://doi.org/10.2514/6.2018-5005

[10] FINGER, F.D., BRAUN, C., BIL, C. Impact of engine failure constraints on the initial sizing of hybrid-electric GA aircraft. AIAA Scitech 2019 Forum, San Diego. https://doi.org/10.2514/6.2019-1812

[11] FINGER, D.F., BRAUN, C., BIL, C. Impact of electric propulsion technology and mission requirements on the performance of VTOL UAVs. CEAS Aeronautical Journal. 2019, 10, 827-843. https://doi.org/10.1007/s13272-018-0352-x

[12] KUŹNIAR, M. Wielokryterialna ocena doboru napędów lotniczych nowej generacji z wykorzystaniem metod energetycznych - PhD Thesis. Rzeszów 2021.

[13] MARIANOWSKI, J., FRĄCZEK, W. CZARNOCKI, F. Założenia podstawowe dla projektu motoszybowca AOSH2. (not publish)

[14] MARIANOWSKI, J., TOMASIEWICZ, J., CZARNOCKI, F. Analiza masowa motoszybowca AOS-H2. (not publish)

[15] ORKISZ, M., KUŹNIAR, M. 3E - a new paradigm for the development of civil aviation. Combustion Engines. 2020, 181(2), 3-10. https://doi.org/10.19206/CE-2020-201

[16] EMRAX d.o.o. https://emrax.com/

[17] Wankel aircraft-engine. WANKEL AG. http://wankel-ag.de

Michał Kuźniar, DEng. - Faculty of Mechanical Engineering and Aeronautics, Rzeszow University of Technology.

e-mail:mkuzniar@prz.edu.pl

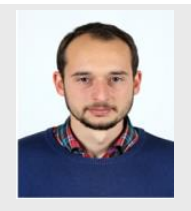

Prof. Marek Orkisz, DSc., DEng. - Faculty of Mechanical Engineering and Aeronautics, Rzeszow University of Technology.

e-mail:mareko@prz.edu.pl

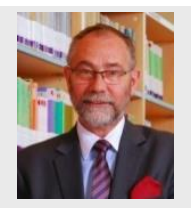

